\title{
DETERMINATION OF PHASE DIAGRAMS AND THERMOSEPARATION BEHAVIOUR OF AQUEOUS TWO-PHASE SYSTEMS COMPOSED OF ETHYLENE OXIDE-PROPYLENE OXIDE RANDOM COPOLYMER AND POTASSIUM PHOSPHATE
}

\author{
Radosław Dembczyński ${ }^{*}$, Wojciech Białas, Tomasz Jankowski \\ Poznan University of Life Sciences, Faculty of Food Science and Nutrition, Department of \\ Biotechnology and Food Microbiology, Wojska Polskiego 48, 60 - 627 Poznań, Poland
}

\begin{abstract}
The application of aqueous two-phase systems (ATPS) is a cost-effective and simple method of protein separation (including enzymes) from complex systems. The first stage of designing the protein purification process in an ATPS involves the identification of the conditions for the formation of a given extraction system. For this purpose, the conditions for the formation of ATPSs in a thermoseparating EO50PO50 polymer/potassium phosphates system have been studied. Factors determining the ATPS formation comprised: separation temperature $\left(4^{\circ} \mathrm{C}\right.$ or $\left.20^{\circ} \mathrm{C}\right)$, phosphate solution $\mathrm{pH}(6,7.5$ or 9$)$ as well as the concentration of $\mathrm{NaCl}$ introduced into the systems $(0.085 \mathrm{M}$, $0.475 \mathrm{M}$ and $0.85 \mathrm{M})$. ATPS without $\mathrm{NaCl}$ were prepared as well. The conditions for the formation of the primary EO50PO50/potassium phosphate ATPS were determined with their phase diagrams. It was observed that with an increase of phosphate $\mathrm{pH}$ and $\mathrm{NaCl}$ concentration in the system, there was a decrease of the EO50PO50 and phosphate concentrations necessary to form a primary ATPS. After the primary two-phase separation, the top phase (rich in the EO50PO50 polymer) was partitioned from the bottom phase (rich in phosphates). Next, by means of polymer phase thermoseparation, a secondary two-phase system was formed. In the secondary EO50PO50/phosphate ATPS, the bottom phase was formed by the concentrated EO50PO50 polymer (30-80\% concentration), while the top phase by a solution composed mainly of water, containing phosphate ions and remains of EO50PO50 polymer (3-7\%).
\end{abstract}

Keywords: aqueous two-phase systems, phase diagrams, thermoseparation, partition coefficient, ethylene oxide-propylene oxide copolymers

\section{INTRODUCTION}

One of the basic problems related to development of different biotechnological preparations is the high cost of downstream processes. The importance of selecting a suitable method of separation is evidenced by the fact that estimated costs of isolation and purification comprise approx. $60-80 \%$ of the preparation production expenses (Dyr and Suttnar, 1997; Lienqueo and Asenjo, 2000; Owen and Chase, 1997). The application of conventional separation methods such as electrophoresis or column chromatography can affect cost-effectiveness of the process, mainly because of the increased costs related to the extension of the process scale. One of the possible solutions is the use of aqueous twophase system extraction during bioseparation processes (Albertsson, 1986; Walter et al., 1985; Xu et al., 2001). Extraction in ATPS presents a range of advantages such as high efficiency of the process, low cost of separation and scale extension as well as preservation of biological activity of the separated

*Corresponding author, e-mail: rdembcz@up.poznan.pl 
molecules (e.g. enzymes). Due to low interfacial tension in ATPS, the risk of protein denaturation during purification is small, compared to traditional extraction systems (e.g. water/organic phase), (Mishima et al., 1998). Therefore, ATPS is extensively used in biotechnology for isolation and purification of proteins (Dembczyński et al., 2010a; Kepka et al., 2005; Rosa et al., 2009). Aqueous two-phase systems are also used in extractive bioconversion processes, which combine biosynthesis of a product with its preliminary partitioning (Banik et al, 2003; Sinha et al., 2000). During the process, product biosynthesis takes place in one of the phases, while the product is extracted into the other phase. There are also attempts to use aqueous two-phase systems in the processes of protein and cell microencapsulation (Elversson and Millqvist-Fureby, 2005; Leja et al, 2009).

Aqueous two-phase systems are formed as a result of mixing adequately concentrated aqueous polymer solutions (e.g. polyethylene glycol and dextran) or polymer and salt solutions (e.g. polyethylene glycol and phosphates). Substances used for the formation of ATPS should be inexpensive, non-toxic, biodegradable or possible to be recovered from a solution and reused in the extraction process (Sarubbo et al., 2000). Therefore, the use of so called thermoseparating polymers has recently been on the increase (Przybycien et al., 2004; Schügerl and Hubbuch, 2005). The polymer-rich phase, obtained as a result of the primary two-phase separation, is then heated up to the temperature that exceeds the cloud point (CP) for a given polymer (Fig. 1). This leads to a new phase separation (secondary two-phase separation), where one of the phases consists mainly of water, while the other comprises the concentrated polymer (Berggren et al., 1995). In the primary two-phase system, the separated protein should selectively migrate to the polymer phase. During the polymer phase thermoseparation, the purified protein moves to the phase consisting mainly of water. The other phase is formed by the concentrated polymer, which can be used for another extraction (Dembczyński et al., 2010b). Thermoseparating polymers most frequently used include synthetic polymers containing oxyethylene (EO) and oxypropylene (PO) groups. Their advantage over other polymers is that their molecule comprises both hydrophilic (EO) and hydrophobic (PO) groups. A selection of an appropriate number of EO and PO units in a molecule allows to obtain a polymer with hydrophilic and hydrophobic properties fulfilling the requirements for a separation process of a given substance (Bakshi et al., 2004). EOPO polymers can be divided into random copolymers and block copolymers (Fig.2). In a random copolymer molecule, the order of monomer arrangement is entirely accidental. On the other hand, a block copolymer molecule comprises polyoxyethylene (PEO) and polyoxypropylene (PPO) groups, formed only of EO and PO groups, respectively. The example is three-block PEO-PPO-PEO copolymers, where both ends of the polymer chain are formed by PEO groups, while the central part of the molecule comprises the PPO group (Torchilin, 2001).

Due to the lack of sufficient knowledge about the mechanisms of molecule separation in ATPS as well as lack of mathematical models that would allow to design a two-phase system, the conditions for each separation in ATPS have to be determined by means of experiments. One of the first stages of developing a process in a ATPS involves phase diagram determination (Rito-Palomares, 2004). Phase diagram is a source of information on the polymer and salt concentrations necessary to form an aqueous two-phase system as well as on the post-separation phase composition. Data on the chemical composition of phases after separation can be used for a separate formation of top and bottom phases appropriately composed and for multistage extraction processes (Albertsson and Tjerneld, 1994).

Figure 3 presents an outline of a phase diagram. TCB curve, representing border concentrations of ATPS-forming compounds, is called a binodal curve. The region above the binodal curve corresponds to the concentrations forming a two-phase system, while the region below the curve represents onephase, homogeneous systems. Point $\mathrm{M}$ represents a two-phase system, partitioned into a top phase, whose composition is described by point $\mathrm{T}$, and bottom phase represented by point $\mathrm{B}$. TMB line which joins the points on the binodal curve is called an equilibrium line or a tie-line (TL). Tie lines designate states of equilibrium. All the systems where the mean content of both the components is described by 
points on one tie line partition into two phases with the same constitution. In the critical point $\mathrm{C}$, the composition and volume of both the phases are theoretically the same (Sinha et al., 2000).

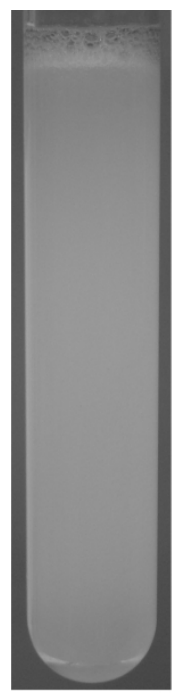

a

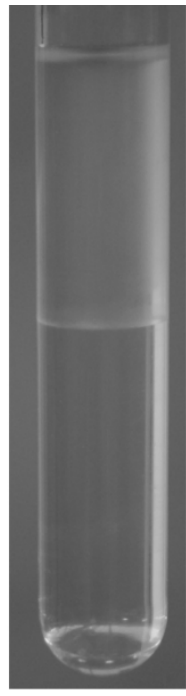

b

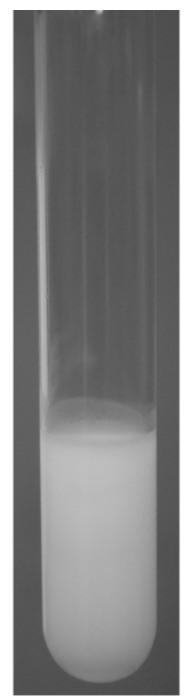

$\mathrm{C}$

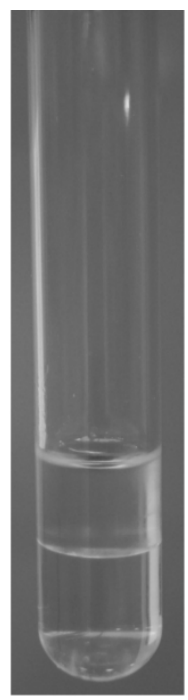

d

Fig. 1. The formation principle of the primary and secondary aqueous two-phase system containing thermoseparating polymer: a) aqueous two-phase emulsion of the primary system, b) primary aqueous two-phase system (upper phase is a polymer phase), c) thermoseparation of a polymer phase, d) secondary aqueous twophase system (upper phase is a water phase, bottom phase is composed of concentrated polymer)

\section{RANDOM COPOLYMER}

\section{$A B A A A B A B B A B A A$}

\section{BLOCK COPOLYMER}

\section{di-block \\ $A A A A A A B B B B B B B$ \\ tri-block \\ $A A A A A B B B B B B B A A A$}

\section{A-hydrophobic group \\ $B$-hydrophilic group}

Fig. 2. The comparison of a random and block copolymer structure

Familiarity with the diagram facilitates the choice of the operational point, whose position against the binodal curve is of great importance. If the operational point is too close to the binodal curve, even a slight dilution of the system can cause a shift of the point to the other side of the curve - into the region of one-phase systems. On the other hand, choosing the operational point that is too far from the binodal curve, where the concentrations of both the compounds are high, poses the risk of precipitation of the separated substance from the solution (Zielińska-Dawidziak and Jankowski, 2002b).

In the literature, there is much information on the formation of traditional aqueous two-phase PEG/dextran and PEG/salt systems (Merchuk et al., 1998; Salabat, 2001; Wu and Zhu, 1999; Zafarani- 
Moattar and Sadeghi, 2001; Zafarani-Moattar and Tolouei, 2008). On the other hand, there is not much data on the formation of aqueous two-phase EO50PO50/phosphate systems (Silverio et al., 2010). Yet, such systems are very attractive because of an easy method of separating the purified protein from the extraction polymer phase (thermoseparation). Within the process of extraction, it is also possible to repeatedly use the thermoseparating EO50PO50 polymer. However, there is a lack of detailed data on the influence of $\mathrm{NaCl}$ and temperature on the formation of EO50PO50/phosphate systems. Sodium chloride is frequently used as a compound that modifies the intensity of electrostatic and hydrophobic interaction of the protein-protein or protein-extraction phase substance types during protein extraction in ATPS (Dembczyński, 2010a; Mistry et al., 1996). A decrease in temperature during enzyme purification, in turn, positively affects their stability. Therefore, experiments within this research aimed at studying how phosphate $\mathrm{pH}$, temperature and the presence of $\mathrm{NaCl}$ affect the formation of primary aqueous two-phase EO50PO50/phosphate systems. Conditions for the formation of the studied aqueous two-phase system were identified as a result of determining appropriate phase diagrams. Moreover, the constitution of secondary two-phase systems was investigated using thermoseparation of the polymer phase, obtained as a result of phase separation within the primary two-phase system.

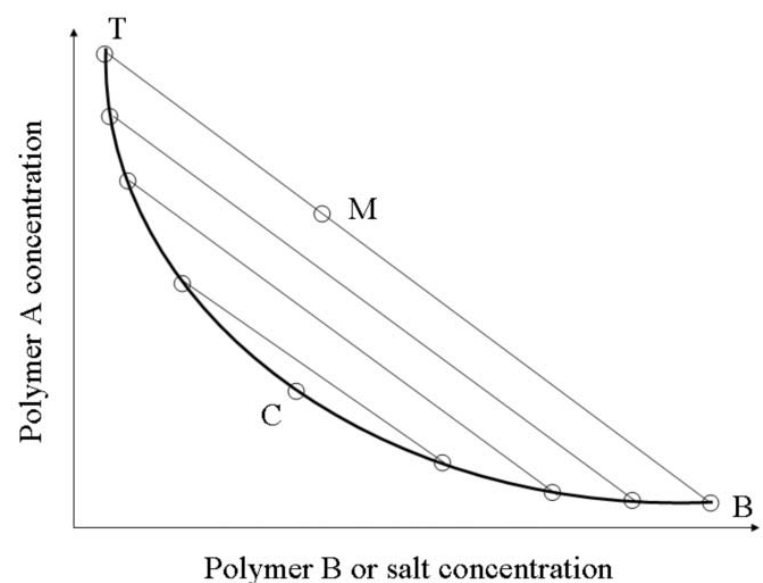

Fig. 3. Generalised phase diagram for two substances in water forming ATPS. T - top phase composition, $\mathrm{B}$ - bottom phase composition, $\mathrm{M}$ - aqueous two-phase emulsion composition, $\mathrm{C}$ - critical point

\section{MATERIALS AND METHODS}

\subsection{Components of the EO50PO50/potassium phosphate two-phase system}

The following compounds were used for the formation of two-phase systems: dipotassium phosphate (Chempur), ortophosphoric acid (Chempur), sodium chloride (Chempur) and EO50PO50 polymer (Sigma-Aldrich). EO50PO50 is a copolymer consisting of oxyethylene groups (50\%) and oxypropylene groups $(50 \%)$. Its relative molecular weight equals to 3900 . Oxyethylene and oxypropylene groups in the molecule are distributed at random. The cloud point for EO50PO50 is $55^{\circ} \mathrm{C}$.

\subsection{Formation of primary and secondary two-phase EO50PO50/potassium phosphate systems}

Aqueous two-phase systems were formed as a result of mixing appropriate weight ratios of EO50PO50 and potassium phosphate aqueous solutions (Table 1). The systems were prepared using phosphate solutions with $\mathrm{pH} 6,7.5$ and 9 with or without sodium chloride in the following concentrations: $0.085 \mathrm{M}, 0.467 \mathrm{M}$, and $0.85 \mathrm{M}$. Appropriate phosphate $\mathrm{pH}$ was obtained by titrating dipotassium phosphate solution with ortophosphoric acid. Dipotassium phosphate and ortophosphoric acid solutions used for titration contained the same concentration of $\mathrm{PO}_{4}{ }^{3-}$ ions. Two-phase systems with $\mathrm{NaCl}$ were 
prepared by mixing polymer and phosphate solutions, which contained $\mathrm{NaCl}$ solved in the same, appropriate concentration. After both the constituents were mixed (when a two-phase emulsion was formed), the separation of the obtained primary systems was carried out at 4 and $20^{\circ} \mathrm{C}$ for $20 \mathrm{~h}$.

After the primary two-phase separation, the top phase (rich in the EO50PO50 polymer) was partitioned from the bottom phase (rich in phosphates). Next, the secondary two-phase system was formed as a result of polymer phase thermoseparation taking place in the temperature of $65^{\circ} \mathrm{C}$ for 15 minutes. Separation of the polymer phase (bottom phase) from the aqueous phase (top phase) was enhanced by centrifugation ( $21000 \mathrm{~g}, 15$ minutes). After the secondary two-phase system was formed, the top phase was separated from the bottom one.

Table 1. Concentration of solutions used for ATPS formation and compositions of formed aqueous-two phase emulsions

\begin{tabular}{|c|c|c|c|c|c|c|}
\hline \multirow{2}{*}{$\begin{array}{c}\text { Number of } \\
\text { ATPS }\end{array}$} & \multicolumn{2}{|c|}{$\begin{array}{c}\text { Solution concentration } \\
{[\% \mathrm{w} / \mathrm{w}]}\end{array}$} & \multicolumn{2}{c|}{ Mass ratio of solutions } & \multicolumn{2}{c|}{$\begin{array}{c}\text { Concentration of } \\
\text { components in the ATPS } \\
\text { emulsion [\% w/w] }\end{array}$} \\
\cline { 2 - 7 } & EO50PO50 & $\mathrm{PO}_{4}{ }^{3-}$ & EO50PO50 & $\mathrm{PO}_{4}{ }^{3-}$ & EO50PO50 & $\mathrm{PO}_{4}{ }^{3-}$ \\
\hline 1 & 24 & 6 & 1 & 1 & 12 & 3 \\
\hline 2 & 30 & 7 & 1 & 1 & 15 & 3.5 \\
\hline 3 & 24 & 16 & 3 & 1 & 18 & 4 \\
\hline 4 & 30 & 15 & 2.33 & 1 & 21 & 4.5 \\
\hline 5 & 40 & 15 & 1.67 & 1 & 25 & 5.5 \\
\hline
\end{tabular}

\subsection{Phase content analysis}

Concentrations of the EO50PO50 polymer and phosphates (as $\mathrm{PO}_{4}{ }^{3-}$ anion) in the obtained top and bottom phases were determined. Moreover, in the systems containing sodium chloride in the $0.467 \mathrm{M}$ and $0.85 \mathrm{M}$ concentrations, the concentrations of chlorides (as $\mathrm{Cl}^{-}$anion) were established.

An analysis of phosphates and chlorides was conducted with the use of HPLC on the Polyspher ICAN1 column (Merck, Germany). The phase comprised a solution of $\mathrm{pH} 4$, containing Tris, boric acid and phthalic acid. The flow rate of the phase was $1.3 \mathrm{ml} / \mathrm{min}$. During the analysis, a constant temperature of $35^{\circ} \mathrm{C}$ was kept. Compound detection was conducted with the wave $\lambda=254 \mathrm{~nm}$ (indirect UV detection), (Czaczyk et al., 2003).

The EO50PO50 concentration was determined using a chromotropic acid method, after the preparation of an absorbance standard curve at $570 \mathrm{~nm}$ with the use of a spectrophotometer (Adler, 1965). This method is based on the hydrolysis of ethylene oxide to form ethylene glycol, which is then oxidised to formaldehyde with sulphuric acid, and determined photometrically, following the reaction with the chromotropic acid.

\subsection{Determination of phase diagrams for primary EO50PO50/potassium phosphate systems}

Binodal curve form was determined on the basis of the concentrations of the EO50PO50 polymer and $\mathrm{PO}_{4}{ }^{3-}$ anion in the top and bottom phases of the primary EO50PO50/potassium phosphate systems. Binodal curves were plotted with Microsoft Excel Solver tool by adjusting the model curve to the obtained experimental data. The following model was used: 


$$
Y=a \exp \left(-\frac{X}{b}\right)+c \exp \left(-\frac{X}{d}\right)
$$

\subsection{Tie line length}

Tie line length was calculated using the equation (Zaslavsky, 1995):

$$
T L L=\left[\left(X_{1}-X_{2}\right)^{2}+\left(Y_{1}-Y_{2}\right)^{2}\right]^{0.5}=\left(\Delta X^{2}-\Delta Y^{2}\right)^{0.5}
$$

\section{6. $\mathrm{Cl}^{-}$anion partition coefficient in primary and secondary systems of EO50PO50/potassium phosphates}

$\mathrm{Cl}^{-}$anion partition coefficient was calculated according to the following equation (Zielińska-Dawidziak and Jankowski, 2002a):

$$
K=\frac{C_{1}}{C_{2}}
$$

\section{RESULTS AND DISCUSSION}

Aqueous two-phase EO50PO50/potassium phosphate system is in fact a modification of the traditional two-phase PEG/phosphates system, in which polyethylene glycol was replaced with a thermoseparating polymer EO50PO50. Phosphates are often used for creating aqueous two-phase systems as opposed to other salts e.g. citrates, which are rarely used (Rito-Palomares, 2004). Sodium chloride, which was added to aqueous two-phase systems, plays the role of a substance modifying the separation parameters of purified proteins. The compound is commonly used also in other protein purification methods such as a lysozyme isolated from chicken egg (Alderton and Fevold, 1946; Kopeć et al., 2000).

During the studies, in order to produce primary two-phase systems, the solutions of EO50PO50 and phosphates of various concentrations were mixed. The two-phase separation took 20 hours. The following factors affected the formation of the two-phase systems: separation temperature $\left(4^{\circ} \mathrm{C}\right.$ or $\left.20^{\circ} \mathrm{C}\right), p H$ of the phosphate solutions $(6,7.5$ or 9$)$ and chloride concentration introduced to the systems $(0.085 \mathrm{M}, 0.475 \mathrm{M}$ and $0.85 \mathrm{M})$. Two-phase systems without sodium chloride were also prepared. After the formation of primary two-phase systems, the concentration of compounds in both phases was determined. Then, the phase diagrams were prepared by adjusting Equation (1) to the experimental data. The model equation coefficients of all the examined types of systems were presented in Table 2. The phase diagrams for two-phase systems comprising of polymer/salt are often determined with the use of exponential equation (Merchuk et al., 1998):

$$
Y=a \exp \left(b X^{0.5}-c X^{3}\right)
$$

The above equation was most often applied for modeling the bimodal curve of two-phase PEG/salt systems (Mistry et al., 1996; Zafarani-Moattar and Hamzehzadeh, 2005). Nevertheless, in two-phase EO50PO50/potassium phosphate systems, the concentration of the polymer in the bottom phase containing a large amount of salt was much higher than in the above mentioned PEG-containing systems. As a result, Equation (1) showed much better adjustment of the model to the experimental data. The compliance of the model with the obtained experimental data was presented on an exemplary phase diagram of a primary EO50PO50/potassium phosphate system (Fig. 4). The diagram also includes the location of tie lines. 
Table 2. Coefficients of a model Equation (1) for binodal curves of primary aqueous two-phase system EO50PO50/potassium phosphate

\begin{tabular}{|c|c|c|c|c|c|c|c|c|c|}
\hline \multirow{3}{*}{$\begin{array}{c}\mathrm{NaCl} \\
{[\mathrm{M}]}\end{array}$} & \multirow{3}{*}{$p H$} & \multicolumn{8}{|c|}{ Model coefficients } \\
\hline & & \multicolumn{4}{|c|}{$4^{\circ} \mathrm{C}$} & \multicolumn{4}{|c|}{$20^{\circ} \mathrm{C}$} \\
\hline & & $\mathrm{a}$ & $\mathrm{b}$ & $\mathrm{c}$ & $\mathrm{d}$ & $\mathrm{a}$ & $\mathrm{b}$ & $\mathrm{c}$ & $\mathrm{d}$ \\
\hline 0 & \multirow{4}{*}{6} & 48.91 & 2.47 & 0.87 & 2.47 & 39.08 & 2.76 & 16.30 & 0.88 \\
\hline 0.085 & & 57.29 & 1.26 & 8.30 & 17.87 & 51.54 & 1.34 & 9.16 & 5.44 \\
\hline 0.467 & & 425.67 & 0.22 & 12.39 & 6.52 & 112.80 & 1.11 & 2.71 & 21.11 \\
\hline 0.85 & & 331.83 & 0.11 & 17.59 & 4.17 & 81.07 & 0.15 & 20.60 & 3.17 \\
\hline 0 & \multirow{4}{*}{7.5} & 30.97 & 1.04 & 13.45 & 4.27 & 39.89 & 0.73 & 17.71 & 3.61 \\
\hline 0.085 & & 61.76 & 0.52 & 11.96 & 10.28 & 61.95 & 0.32 & 19.92 & 4.68 \\
\hline 0.467 & & 116.78 & 0.25 & 16.66 & 4.73 & 115.69 & 0.20 & 22.27 & 3.36 \\
\hline 0.85 & & 803.23 & 0.04 & 23.43 & 4.74 & 246.65 & 0.08 & 38.98 & 1.52 \\
\hline 0 & \multirow{4}{*}{9} & 46.00 & 0.49 & 8.77 & 6.55 & 70.07 & 0.16 & 28.17 & 2.29 \\
\hline 0.085 & & 55.18 & 0.50 & 13.78 & 8.01 & 257.33 & 0.20 & 13.94 & 5.40 \\
\hline 0.467 & & 253.15 & 0.17 & 14.25 & 4.30 & 135.05 & 0.18 & 24.10 & 2.75 \\
\hline 0.85 & & 92.92 & 0.10 & 17.52 & 2.97 & 786.49 & 0.06 & 22.82 & 2.11 \\
\hline
\end{tabular}

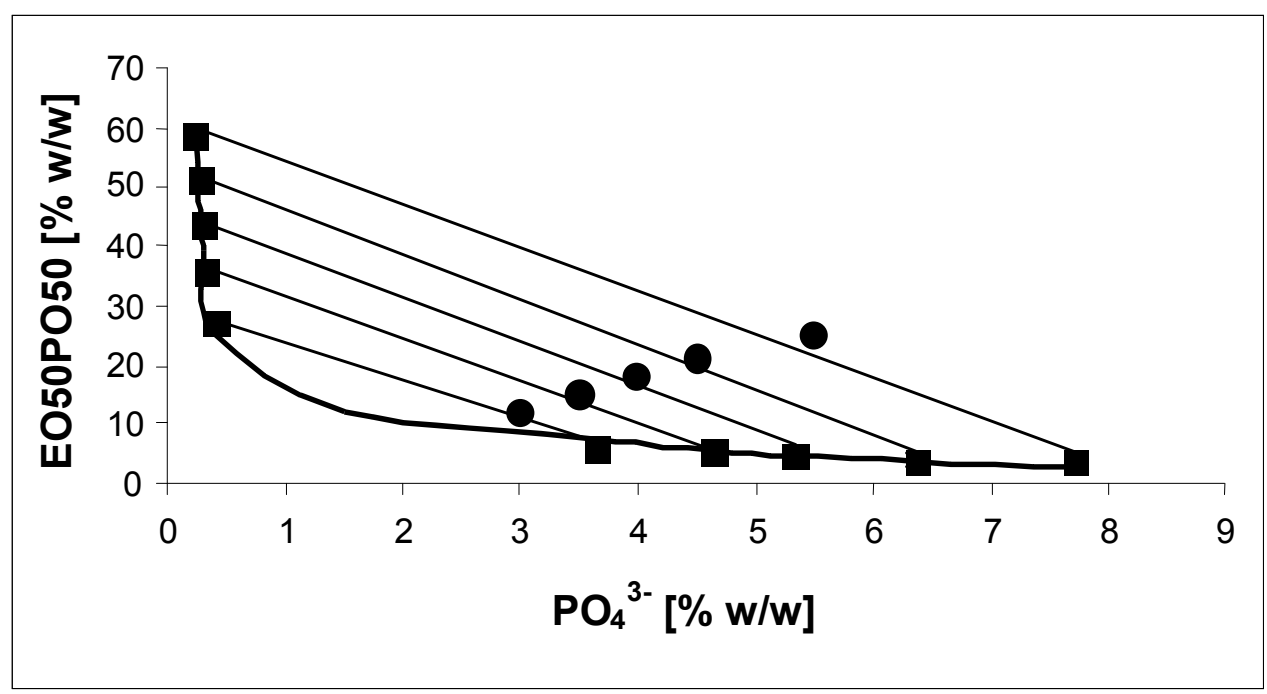

Fig. 4. An example of a phase diagram for the primary aqueous two-phase system EO50PO50/potassium phosphate ( $\mathrm{pH} 6,4^{\circ} \mathrm{C}$, sodium chloride concentration $\left.0.85 \mathrm{M}\right)$.

- operational point denoting concentration of components in the ATPS emulsion - determined experimentally concentration of components in the top and bottom phase binodal curve model

\subsection{The influence of potassium phosphate $\mathrm{pH}$ on the formation of primary two-phase systems}

It was concluded on the basis of the conducted experiments, that the $\mathrm{pH}$ of the phosphates used for system preparation had the highest influence on the formation of the primary two-phase EO50PO50/phosphate systems (Fig. 5). It was observed that the formation of two-phase systems required lower concentrations of $\mathrm{PO}_{4}{ }^{3-}$ anion and polymer when phosphate $\mathrm{pH}$ increased. It was manifested in a gradual shift of bimodal curves towards lower concentrations of $\mathrm{PO}_{4}{ }^{3-}$ and EO50PO50 on the phase diagram. A similar phenomenon was observed by Sebastiao et al. (1996), who analysed aqueous two-phase PEG/phosphate systems as well as Silverio et al. (2010), who investigated two- 
phase Ucon/sodium phosphate and Ucon/potassium phosphate systems. Along with the increasing phosphate $\mathrm{pH}$ in the examined systems, the polymer concentration in the top phase and the phosphate concentration in the bottom phase increased as well. From the practical point of view, it means that smaller amounts of single components during the extraction of proteins in the phosphate-containing systems of $\mathrm{pH} 9$ have to be used. Such systems are characterised by the smallest region below the binodal curve, which is the region of the compound concentrations, which did not produce two-phase system. For this reason, during the protein extraction, they will be the most resistant to dilution because of using a large amount of the solution from which the protein will be separated.

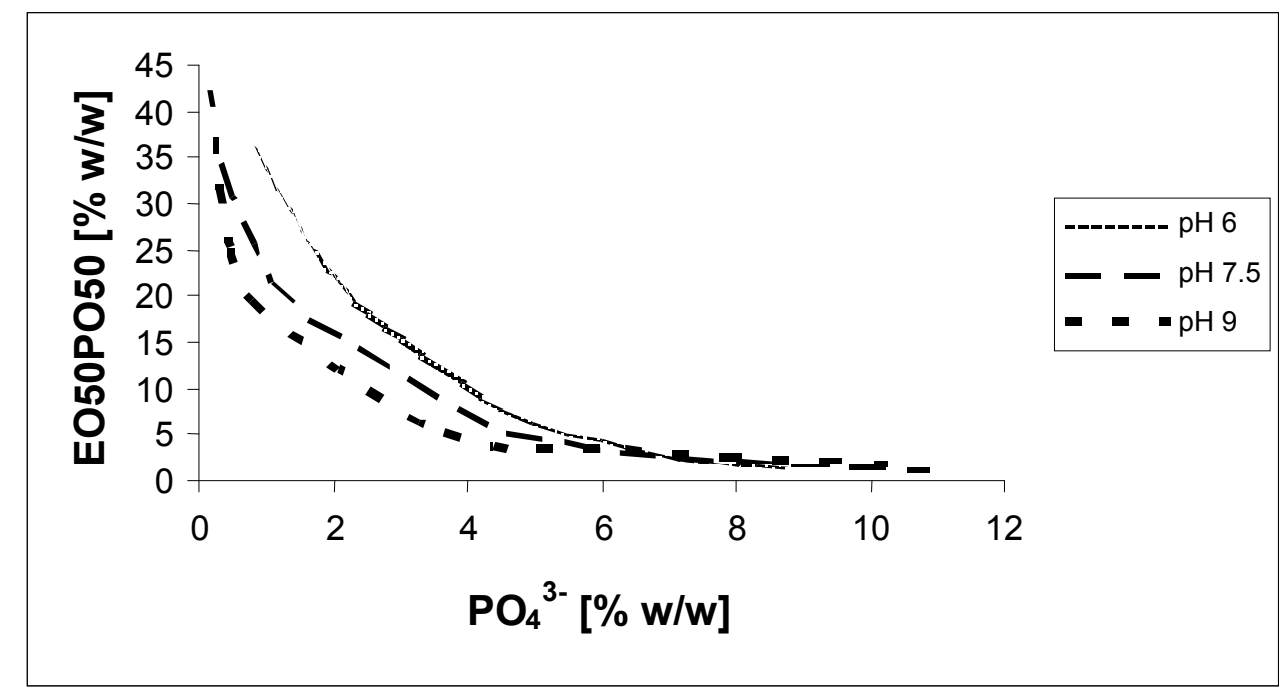

Fig. 5. The effect of $\mathrm{pH}$ on the position of binodal curves in the phase diagram of primary aqueous two-phase system EO50PO50/potassium phosphate $\left(4^{\circ} \mathrm{C}\right.$, sodium chloride concentration $\left.0 \mathrm{M}\right)$

\subsection{The influence of sodium chloride on the formation of primary two-phase systems}

Two-phase system region (the field above the binodal curve) increased along with the increase of the sodium chloride concentration in the two-phase system. It was particularly important in the systems which contained its highest concentration of $0.85 \mathrm{M}$ (Fig. 6). The systems where $0.467 \mathrm{M}$ of $\mathrm{NaCl}$ was added were characterised by a slightly smaller two-phase area. Introducing sodium chloride into the primary two-phase EO50PO50/potassium phosphate systems also resulted in the increase of the tie lines length (Tables 4 and 5). This was particularly pronounced in the systems with $0.85 \mathrm{M}$ of sodium chloride, formed with EO50PO50 and phosphates of $p H 7.5$ and 9 in $20^{\circ} \mathrm{C}$. Along with the increase of sodium chloride concentration in the system, the concentration of EO50PO50 also increased in the top phase and phosphates in the bottom phase, while the concentration of EO50PO50 in the bottom phase decreased. The increase of two-phase region can be also induced by substances different from sodium chloride, such as surfactants. Cunha et al. (2000) noticed that in the systems composed of two polymers (EO50PO50 and hydroxypropyl starch) with high concentrations of sodium laureate (100-200 mM), the binodal curve was moved to lower polymer concentrations.

\subsection{The influence of temperature on the formation of primary two-phase systems}

Based on the conducted experiments, it was concluded that the temperature in which the primary phase separation takes place does not influence the form of the bimodal curve on the phase diagram. The binodal curves reflecting the systems formed at 4 and $20^{\circ} \mathrm{C}$ practically overlapped (Fig. 7). However, the analysis of the tie line length and the compound concentrations in both the phases revealed that the temperature influenced the formation process of the primary two-phase EO50PO50/phosphate systems. 
Basically, the systems formed at $20^{\circ} \mathrm{C}$ had longer tie lines compared to the respective systems formed at $4^{\circ} \mathrm{C}$. Another result of the forming temperature increase was that along with the increase of the tie line length of the examined system, the polymer concentration increased in the top phase, while the concentration of phosphates decreased in the bottom phase (Table 3). A similar phenomenon was observed by Svensson et al. (1999) in a two-phase system composed of Pluronic p105 block polymer/ T500 dextrane. Along with the increase of formation temperature from 5 to $30^{\circ} \mathrm{C}$, the concentration of Pluronic in the top phase increased and the dextrane concentration in the bottom phase decreased at the same time. The process was a consequence of water redistribution from the top phase to the bottom phase. As a result, the hydrophobicity in the top phase and the partition coefficients of the hydrophobic substances (e.g. peptides containing tryptophan) increased. Summarising the influence of temperature on the formation process of primary two-phase systems, it should be emphasized that this factor did not affect the shape and location of the binodal curve on the EO50PO50/potassium phosphate phase diagrams. However, a different phenomenon was observed in the aqueous two-phase system EO50PO50/ammonium sulfate ( $\mathrm{Li}$ et al., 2000; Li et al., 1999; Pereira et al., 2003). For EO50PO50/ammonium sulfate it was found that an increase of temperature moved the bimodal curve on the phase diagram towards lower concentrations of polymer and sulfate. Temperature can, however, influence the concentrations of compounds in different phases of the system and hence influence the partition coefficient values of the separated compounds.

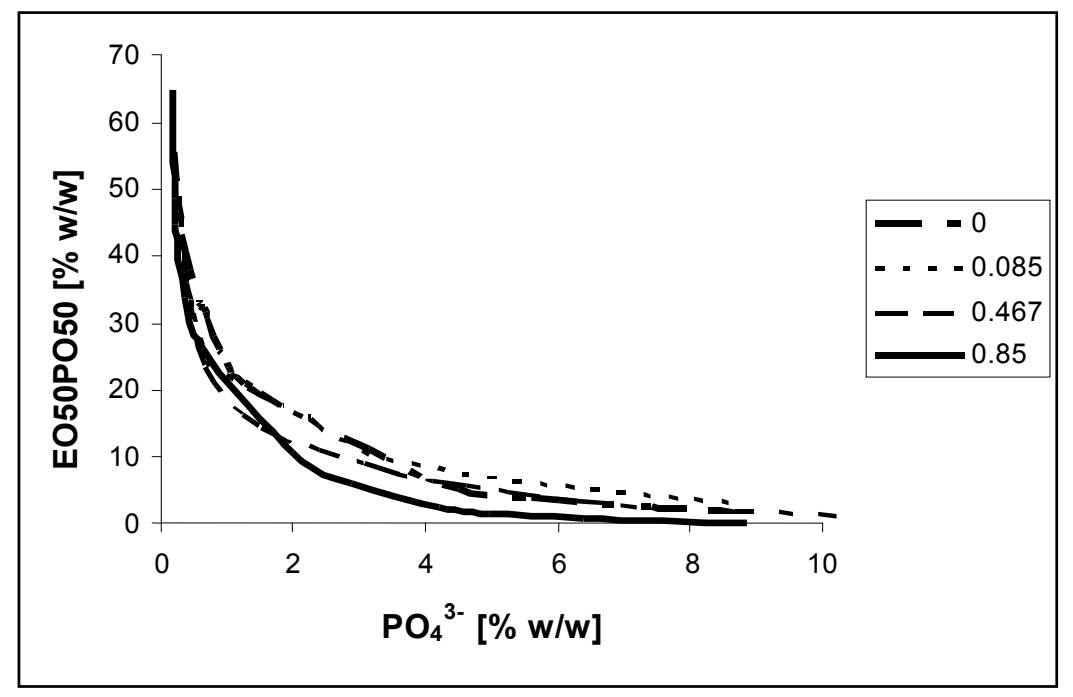

Fig. 6. The effect of sodium chloride concentration (M) on the position of binodal curves in the phase diagram of primary aqueous two-phase system EO50PO50/potassium phosphate $\left(20^{\circ} \mathrm{C}, \mathrm{pH} 7.5\right)$

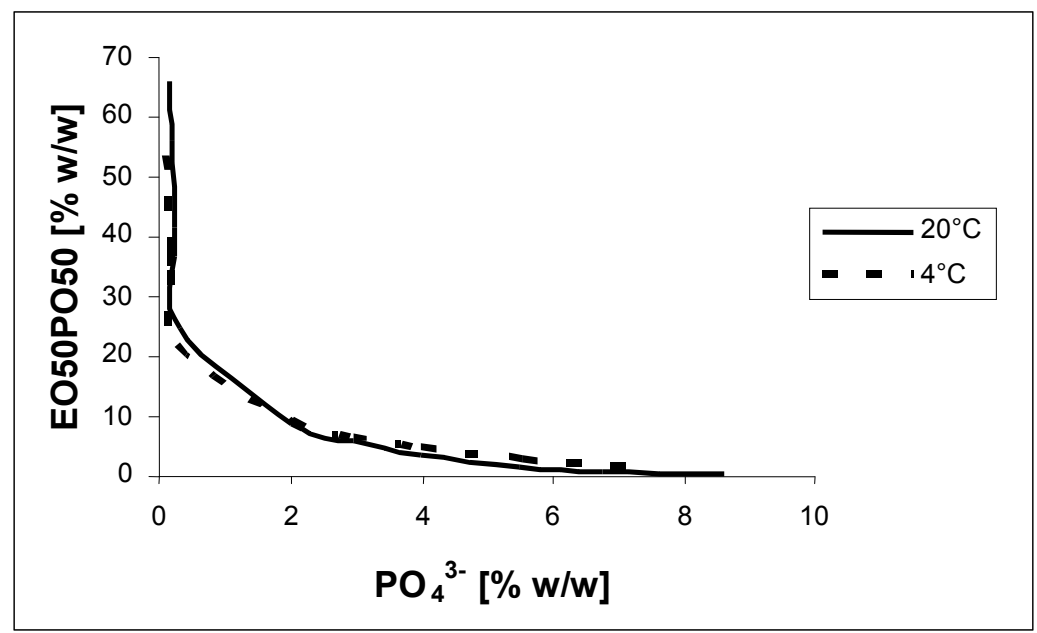

Fig. 7. The effect of temperature on the position of binodal curves in the phase diagram of primary aqueous twophase system EO50PO50/potassium phosphate ( $p H 9$, sodium chloride concentration $0.85 \mathrm{M}$ ) 
Table 3. The comparison of EO50PO50 and $\mathrm{PO}_{4}{ }^{3-}$ concentration in the phases of the primary aqueous two-phase systems EO50PO50/potassium phosphate formed in different temperatures $(\mathrm{pH} 9$, sodium chloride concentration $0.85 \mathrm{M}$ )

\begin{tabular}{|c|c|c|c|c|c|c|c|c|c|}
\hline $\begin{array}{c}\text { Concentration of } \\
\text { components in the } \\
\text { ATPS emulsion } \\
{[\% \mathrm{w} / \mathrm{w}]}\end{array}$ & \multicolumn{4}{|c|}{$\begin{array}{c}\text { Concentration of components } \\
\text { in the top phase } \\
{[\% \mathrm{w} / \mathrm{w}]}\end{array}$} & \multicolumn{4}{c|}{$\begin{array}{c}\text { Concentration of components } \\
\text { in the bottom phase } \\
{[\% \mathrm{w} / \mathrm{w}]}\end{array}$} \\
\hline \multirow{2}{*}{ EO50PO50 } & $\mathrm{PO}_{4}{ }^{3-}$ & \multicolumn{2}{|c|}{ EO50PO50 } & \multicolumn{2}{|c|}{$\mathrm{PO}_{4}{ }^{3-}$} & \multicolumn{3}{|c|}{ EO50PO50 } & \multicolumn{2}{c|}{$\mathrm{PO}_{4}{ }^{3-}$} \\
\cline { 3 - 11 } & $4{ }^{\circ} \mathrm{C}$ & $20^{\circ} \mathrm{C}$ & $4{ }^{\circ} \mathrm{C}$ & $20^{\circ} \mathrm{C}$ & $4{ }^{\circ} \mathrm{C}$ & $20^{\circ} \mathrm{C}$ & $4{ }^{\circ} \mathrm{C}$ & $20^{\circ} \mathrm{C}$ \\
\hline 12 & 3 & 23.18 & 24.90 & 0.27 & 0.30 & 5.30 & 4.09 & 2.95 & 2.92 \\
\hline 15 & 3.5 & 29.89 & 32.53 & 0.16 & 0.23 & 5.18 & 3.54 & 3.98 & 3.97 \\
\hline 18 & 4 & 36.60 & 46.10 & 0.15 & 0.21 & 3.40 & 2.33 & 5.55 & 5.49 \\
\hline 21 & 4.5 & 45.20 & 54.60 & 0.14 & 0.18 & 2.00 & 1.19 & 7.13 & 6.73 \\
\hline 25 & 5.5 & 52.91 & 66.62 & 0.09 & 0.17 & 0.24 & 0.12 & 9.23 & 8.59 \\
\hline
\end{tabular}

\subsection{Formation of secondary two-phase systems}

After the primary separation, the top phase (rich in the EO50PO50 polymer) was separated from the bottom phase (rich in phosphates). The polymer-rich phase was subjected to thermoseparation by increasing the temperature above the cloud point of the used polymer. In the earlier work, Johansson et al. (1997) found that an increase of thermoseparation temperature had almost no effect on polymerwater concentrations between the phases after temperature-induced phase partitioning. Hence, in this study only one thermoseparation temperature of $65^{\circ} \mathrm{C}$ was used. As a result of heating the polymer-rich phase, two new phases in the state of equilibrium were formed (secondary system): a bottom phase with high concentration of polymer and a top aqueous phase.

The polymer concentration, both in the bottom and top phases of the secondary system increased along with the rise in the polymer concentration in the primary system (Tables 6-9). The polymer present in the bottom phase of the secondary system can be reused for the formation of new two-phase systems. Therefore, obtaining possibly the highest concentration of the polymer is desirable. The highest recovery of EO50PO50 was obtained in the bottom phases of the secondary systems crated as a result of thermoseparation of the top phases of primary systems, which contained $0.085 \mathrm{M}$ of sodium chloride. In some systems, the polymer concentration was higher than $85 \%$ (as mentioned above). A further increase of the sodium chloride concentration in the primary EO50PO50/phosphate systems resulted in decreasing the polymer concentration in the bottom phases after thermoseparation. The lowest polymer concentrations were obtained in the polymer phases after thermoseparation of the primary system top phases, which contained $0.85 \mathrm{M}$ of sodium chloride. They were only $45-55 \%$ (mentioned above). Additionally, in the case of two-phase systems with $0.85 \mathrm{M}$ of sodium chloride addition, heating of all the top phases in the primary systems, which contained the highest concentrations of EO50PO50, did not result in secondary system formation.

During protein separation in two-phase systems, it is important that the lowest possible polymer concentration be left in the aqueous phase after thermoseparation because it constitutes contamination in the preparation of the isolated molecule. In the systems studied, the aqueous phase contained 2-12\% of polymer (mentioned above). Lower remains of EO50PO50 in the top phases of the secondary systems corresponded to lower polymer concentrations in the primary systems.

The concentration of thermoseparating polymer in the secondary system phases examined in this study were similar to the data published in other studies. Pereira et al. (2003) examined systems composed of the Ucon thermoseparating polymer/ammonium sulfate. The bottom phase contained the polymer in the 
concentration of $83-87 \%$ after thermoseparation at $80^{\circ} \mathrm{C}$. Lower concentration of the Breox thermoseparating polymer in the polymer phase was obtained by Cunha et al. (1998). They amounted to $60-65 \%$, while the polymer concentrations in the aqueous phase were $1-3 \%$.

Table 4. Tie line length (TLL) for the primary aqueous two-phase system EO50PO50/potassium phosphate (sodium chloride concentration 0 and $0.085 \mathrm{M}$ )

\begin{tabular}{|c|c|c|c|c|c|}
\hline \multicolumn{2}{|c|}{$\begin{array}{c}\text { Concentration of } \\
\text { components in the } \\
\text { ATPS emulsion } \\
{[\% \mathrm{w} / \mathrm{w}]}\end{array}$} & \multirow{2}{*}{$\begin{array}{c}\text { Concentration } \\
\text { of } \mathrm{NaCl} \text { in } \\
\text { the ATPS } \\
\text { emulsion } \\
{[\mathrm{M}]}\end{array}$} & \multirow[t]{2}{*}{$p H$} & \multicolumn{2}{|c|}{$\begin{array}{l}T L L \\
{[\%]}\end{array}$} \\
\hline EO50PO50 & $\mathrm{PO}_{4}^{3-}$ & & & $4^{\circ} \mathrm{C}$ & $20^{\circ} \mathrm{C}$ \\
\hline 12 & 3 & \multirow{15}{*}{0} & \multirow{5}{*}{6} & - & - \\
\hline 15 & 3.5 & & & 10.06 & 14.38 \\
\hline 18 & 4 & & & 21.13 & 22.66 \\
\hline 21 & 4.5 & & & 27.81 & 32.30 \\
\hline 25 & 5.5 & & & 34.99 & 42.26 \\
\hline 12 & 3 & & \multirow{5}{*}{7.5} & 12.00 & 14.96 \\
\hline 15 & 3.5 & & & 19.62 & 20.82 \\
\hline 18 & 4 & & & 25.65 & 28.71 \\
\hline 21 & 4.5 & & & 30.84 & 35.15 \\
\hline 25 & 5.5 & & & 34.43 & 42.70 \\
\hline 12 & 3 & & \multirow{5}{*}{9} & 11.86 & 15.87 \\
\hline 15 & 3.5 & & & 21.28 & 22.56 \\
\hline 18 & 4 & & & 27.30 & 30.77 \\
\hline 21 & 4.5 & & & 34.16 & 38.67 \\
\hline 25 & 5.5 & & & 40.12 & 47.05 \\
\hline 12 & 3 & \multirow{15}{*}{0.085} & \multirow{5}{*}{6} & 5.09 & 10.52 \\
\hline 15 & 3.5 & & & 13.71 & 19.87 \\
\hline 18 & 4 & & & 18.89 & 25.92 \\
\hline 21 & 4.5 & & & 26.29 & 34.53 \\
\hline 25 & 5.5 & & & 39.78 & 45.47 \\
\hline 12 & 3 & & \multirow{5}{*}{7.5} & 11.06 & 17.11 \\
\hline 15 & 3.5 & & & 18.03 & 25.04 \\
\hline 18 & 4 & & & 25.38 & 34.89 \\
\hline 21 & 4.5 & & & 33.13 & 43.22 \\
\hline 25 & 5.5 & & & 47.38 & 53.40 \\
\hline 12 & 3 & & \multirow{5}{*}{9} & 12.45 & 18.20 \\
\hline 15 & 3.5 & & & 19.04 & 26.12 \\
\hline 18 & 4 & & & 26.07 & 36.79 \\
\hline 21 & 4.5 & & & 33.93 & 45.44 \\
\hline 25 & 5.5 & & & 41.96 & 57.28 \\
\hline
\end{tabular}

- formation of an aqueous two-phase system did not occur 
Table 5. Tie line length (TLL) for the primary aqueous two-phase system EO50PO50/potassium phosphate (sodium chloride concentration 0.467 and $0.85 \mathrm{M}$ )

\begin{tabular}{|c|c|c|c|c|c|}
\hline \multicolumn{2}{|c|}{$\begin{array}{c}\text { Concentration of } \\
\text { components in the } \\
\text { ATPS emulsion } \\
{[\% \mathrm{w} / \mathrm{w}]}\end{array}$} & \multirow{2}{*}{$\begin{array}{c}\text { Concentration } \\
\text { of } \mathrm{NaCl} \text { in } \\
\text { the ATPS } \\
\text { emulsion } \\
{[\mathrm{M}]}\end{array}$} & \multirow[t]{2}{*}{$p H$} & \multicolumn{2}{|c|}{$\begin{array}{l}T L L \\
{[\%]}\end{array}$} \\
\hline EO50PO50 & $\mathrm{PO}_{4}^{3-}$ & & & $4^{\circ} \mathrm{C}$ & $20^{\circ} \mathrm{C}$ \\
\hline 12 & 3 & \multirow{15}{*}{0.467} & \multirow{5}{*}{6} & 0.47 & 8.44 \\
\hline 15 & 3.5 & & & 0.42 & 17.38 \\
\hline 18 & 4 & & & 0.42 & 23.45 \\
\hline 21 & 4.5 & & & 0.37 & 30.19 \\
\hline 25 & 5.5 & & & 0.30 & 41.86 \\
\hline 12 & 3 & & \multirow{5}{*}{7.5} & 0.42 & 11.62 \\
\hline 15 & 3.5 & & & 0.39 & 19.47 \\
\hline 18 & 4 & & & 0.37 & 25.69 \\
\hline 21 & 4.5 & & & 0.34 & 32.66 \\
\hline 25 & 5.5 & & & 0.30 & 46.43 \\
\hline 12 & 3 & & \multirow{5}{*}{9} & 0.42 & 12.89 \\
\hline 15 & 3.5 & & & 0.38 & 20.83 \\
\hline 18 & 4 & & & 0.35 & 26.82 \\
\hline 21 & 4.5 & & & 0.33 & 35.63 \\
\hline 25 & 5.5 & & & 0.30 & 44.83 \\
\hline 12 & 3 & \multirow{15}{*}{0.850} & \multirow{5}{*}{6} & 0.30 & 16.76 \\
\hline 15 & 3.5 & & & 0.28 & 24.75 \\
\hline 18 & 4 & & & 0.23 & 30.91 \\
\hline 21 & 4.5 & & & 0.23 & 38.35 \\
\hline 25 & 5.5 & & & 0.22 & 45.33 \\
\hline 12 & 3 & & \multirow{5}{*}{7.5} & - & \\
\hline 15 & 3.5 & & & 0.25 & 20.94 \\
\hline 18 & 4 & & & 0.21 & 26.94 \\
\hline 21 & 4.5 & & & 0.16 & 38.05 \\
\hline 25 & 5.5 & & & 0.15 & 56.63 \\
\hline 12 & 3 & & \multirow{5}{*}{9} & 0.26 & 18.09 \\
\hline 15 & 3.5 & & & 0.23 & 25.01 \\
\hline 18 & 4 & & & 0.21 & 33.64 \\
\hline 21 & 4.5 & & & 0.20 & 43.76 \\
\hline 25 & 5.5 & & & 0.17 & 53.58 \\
\hline
\end{tabular}

- formation of an aqueous two-phase system did not occur 
Table 6. The concentration of EO50PO50 and $\left(\mathrm{PO}_{4}\right)^{3-}$ in the phases of the secondary aqueous two-phase system EO50PO50/potassium phosphate (sodium chloride concentration in the primary ATPS $-0 \mathrm{M}$ )

\begin{tabular}{|c|c|c|c|c|c|c|c|c|c|c|c|c|c|}
\hline \multirow{4}{*}{\multicolumn{2}{|c|}{$\begin{array}{l}\text { Concentration of } \\
\text { components in the } \\
\text { primary ATPS } \\
\text { emulsion }[\% \mathrm{w} / \mathrm{w}]\end{array}$}} & \multicolumn{12}{|c|}{$\begin{array}{l}\text { The EO50PO50 and }\left(\mathrm{PO}_{4}\right)^{3-} \text { concentration after thermoseparation of top phase of the primary ATPS } \\
\text { EO50PO50/potassium phosphate [\% } / \mathrm{w}]\end{array}$} \\
\hline & & \multicolumn{4}{|c|}{$\mathrm{pH} 6$} & \multicolumn{4}{|c|}{$\mathrm{pH} 7.5$} & \multicolumn{4}{|c|}{$\mathrm{pH} 9$} \\
\hline & & \multicolumn{12}{|c|}{ Temperature of the primary ATPS formation $20^{\circ} \mathrm{C}$} \\
\hline & & \multicolumn{2}{|c|}{ Bottom phase } & \multicolumn{2}{|c|}{ Top phase } & \multicolumn{2}{|c|}{ Bottom phase } & \multicolumn{2}{|c|}{ Top phase } & \multicolumn{2}{|c|}{ Bottom phase } & \multicolumn{2}{|c|}{ Top phase } \\
\hline $\begin{array}{l}\text { EO50 } \\
\text { PO50 }\end{array}$ & $\left(\mathrm{PO}_{4}\right)^{3-}$ & $\begin{array}{l}\text { EO50 } \\
\text { PO50 }\end{array}$ & $\left(\mathrm{PO}_{4}\right)^{3-}$ & $\begin{array}{l}\text { EO50 } \\
\text { PO50 }\end{array}$ & $\left(\mathrm{PO}_{4}\right)^{3-}$ & $\begin{array}{l}\text { EO50 } \\
\text { PO50 }\end{array}$ & $\left(\mathrm{PO}_{4}\right)^{3-}$ & $\begin{array}{l}\text { EO50 } \\
\text { PO50 }\end{array}$ & $\left(\mathrm{PO}_{4}\right)^{3-}$ & $\begin{array}{l}\text { EO50 } \\
\text { PO50 }\end{array}$ & $\left(\mathrm{PO}_{4}\right)^{3-}$ & $\begin{array}{l}\text { EO50 } \\
\text { PO50 }\end{array}$ & $\left(\mathrm{PO}_{4}\right)^{3-}$ \\
\hline 3 & 12 & \multicolumn{4}{|c|}{-} & 54.0 & 0.8 & 3.8 & 2.4 & 48.0 & 0.9 & 4.5 & 2.5 \\
\hline 3.5 & 5 & 49.0 & 0.9 & 5.3 & 3.4 & 56.3 & 0.3 & 5.4 & 1.9 & 57.1 & 0.7 & 5.7 & 2.0 \\
\hline 4 & 18 & 50.6 & 0.8 & 5.8 & 2.9 & 62.8 & 0.2 & 5.8 & 1.9 & 59.7 & 0.3 & 6.7 & 1.5 \\
\hline 4.5 & 21 & 58.9 & 0.2 & 7.2 & 2.6 & 67.7 & 0.2 & 6.4 & 1.5 & 66.3 & 0.3 & 7.4 & 1.5 \\
\hline 5.5 & 25 & 69.6 & 0.2 & 8.0 & 2.5 & 70.8 & 0.2 & 7.0 & 1.2 & 78.5 & 0.2 & $\mathrm{bt}$ & $\mathrm{bt}$ \\
\hline \multirow{4}{*}{\multicolumn{2}{|c|}{$\begin{array}{l}\text { Concentration of } \\
\text { components in the } \\
\text { primary ATPS } \\
\text { emulsion }[\% \mathrm{w} / \mathrm{w}]\end{array}$}} & \multirow{2}{*}{\multicolumn{4}{|c|}{$\mathrm{pH} 6$}} & \multirow{2}{*}{\multicolumn{4}{|c|}{$\mathrm{pH} 7.5$}} & & & & \\
\hline & & & & & & & & & & \multicolumn{4}{|c|}{ pH 9} \\
\hline & & \multicolumn{12}{|c|}{ Temperature of the primary ATPS formation $4^{\circ} \mathrm{C}$} \\
\hline & & \multicolumn{2}{|c|}{ Bottom phase } & \multicolumn{2}{|c|}{ Top phase } & \multicolumn{2}{|c|}{ Bottom phase } & \multicolumn{2}{|c|}{ Top phase } & \multicolumn{2}{|c|}{ Bottom phase } & \multicolumn{2}{|c|}{ Top phase } \\
\hline $\begin{array}{l}\text { EO50 } \\
\text { PO50 }\end{array}$ & $\left(\mathrm{PO}_{4}\right)^{3-}$ & $\begin{array}{l}\text { EO50 } \\
\text { PO50 }\end{array}$ & $\left(\mathrm{PO}_{4}\right)^{3-}$ & $\begin{array}{l}\text { EO50 } \\
\text { PO50 }\end{array}$ & $\left(\mathrm{PO}_{4}\right)^{3-}$ & $\begin{array}{l}\mathrm{EO} 50 \\
\mathrm{PO} 50\end{array}$ & $\left(\mathrm{PO}_{4}\right)^{3-}$ & $\begin{array}{l}\text { EO50 } \\
\text { PO50 }\end{array}$ & $\left(\mathrm{PO}_{4}\right)^{3-}$ & $\begin{array}{l}\text { EO50 } \\
\text { PO50 } \\
\end{array}$ & $\left(\mathrm{PO}_{4}\right)^{3-}$ & $\begin{array}{l}\text { EO50 } \\
\text { PO50 } \\
\end{array}$ & $\left(\mathrm{PO}_{4}\right)^{3-}$ \\
\hline 3 & 12 & \multicolumn{4}{|c|}{-} & 41.6 & 0.8 & 3.8 & 3.0 & 39.8 & 0.5 & 5.4 & 2.4 \\
\hline 3.5 & 5 & 49.0 & 0.7 & 5.1 & 3.5 & 50.1 & 0.6 & 4.3 & 2.3 & 44.1 & 0.4 & 5.5 & 2.1 \\
\hline 4 & 18 & 52.5 & 0.6 & 5.2 & 3.0 & 51.5 & 0.5 & 6.5 & 2.1 & 52.3 & 0.3 & 6.4 & 2.1 \\
\hline 4.5 & 21 & 72.4 & 0.4 & 5.4 & 3.0 & 52.9 & 0.3 & 6.7 & 2.0 & 68.1 & 0.2 & 8.1 & 2.0 \\
\hline 5.5 & 25 & 78.0 & 0.3 & 6.6 & 2.8 & 74.8 & 0.2 & 7.3 & 1.6 & 75.8 & 0.1 & 9.1 & 1.4 \\
\hline
\end{tabular}

- formation of the primary aqueous two-phase system did not occur

$\mathrm{bt}$ - formation of the secondary aqueous two-phase system did not occur

Table 7. The concentration of EO50PO50 and $\left(\mathrm{PO}_{4}\right)^{3-}$ in the phases of the secondary aqueous two-phase system EO50PO50/potassium phosphate (sodium chloride concentration in the primary ATPS - 0.085 M)

\begin{tabular}{|c|c|c|c|c|c|c|c|c|c|c|c|c|c|}
\hline \multirow{4}{*}{\multicolumn{2}{|c|}{$\begin{array}{l}\text { Concentration of } \\
\text { components in the } \\
\text { primary ATPS } \\
\text { emulsion }[\% \mathrm{w} / \mathrm{w}]\end{array}$}} & \multicolumn{12}{|c|}{$\begin{array}{l}\text { The EO50PO50 and }\left(\mathrm{PO}_{4}\right)^{3-} \text { concentration after thermoseparation of top phase of the primary ATPS } \\
\text { EO50PO50/potassium phosphate [\% } / \mathrm{w}]\end{array}$} \\
\hline & & \multicolumn{4}{|c|}{ pH 6} & \multicolumn{4}{|c|}{$\mathrm{pH} 7.5$} & \multicolumn{4}{|c|}{ pH 9} \\
\hline & & \multicolumn{12}{|c|}{ Temperature of the primary ATPS formation $20^{\circ} \mathrm{C}$} \\
\hline & & \multicolumn{2}{|c|}{ Bottom phase } & \multicolumn{2}{|c|}{ Top phase } & \multicolumn{2}{|c|}{ Bottom phase } & \multicolumn{2}{|c|}{ Top phase } & \multicolumn{2}{|c|}{ Bottom phase } & \multicolumn{2}{|c|}{ Top phase } \\
\hline $\begin{array}{l}\text { EO50 } \\
\text { PO50 }\end{array}$ & $\left(\mathrm{PO}_{4}\right)^{3-}$ & $\begin{array}{l}\text { EO50 } \\
\text { PO50 }\end{array}$ & $\left(\mathrm{PO}_{4}\right)^{3-}$ & $\begin{array}{l}\text { EO50 } \\
\text { PO50 }\end{array}$ & $\left(\mathrm{PO}_{4}\right)^{3-}$ & $\begin{array}{l}\text { EO50 } \\
\text { PO50 }\end{array}$ & $\left(\mathrm{PO}_{4}\right)^{3-}$ & $\begin{array}{l}\text { EO50 } \\
\text { PO50 }\end{array}$ & $\left(\mathrm{PO}_{4}\right)^{3-}$ & $\begin{array}{l}\text { EO50 } \\
\text { PO50 }\end{array}$ & $\left(\mathrm{PO}_{4}\right)^{3-}$ & $\begin{array}{l}\text { EO50 } \\
\text { PO50 }\end{array}$ & $\left(\mathrm{PO}_{4}\right)^{3-}$ \\
\hline 3 & 12 & 39.5 & 0.3 & 3.7 & 1.6 & 48.2 & 0.2 & 3.6 & 1.3 & 47.4 & 0.1 & 4.5 & 2.5 \\
\hline 3.5 & 5 & 43.9 & 0.2 & 4.6 & 1.5 & 61.7 & 0.1 & 4.3 & 1.2 & 64.4 & 0.1 & 5.7 & 2.0 \\
\hline 4 & 18 & 51.1 & 0.2 & 4.6 & 1.4 & 71.5 & 0.1 & 4.8 & 1.1 & 67.2 & 0.1 & 6.7 & 1.5 \\
\hline 4.5 & 21 & 54.7 & 0.2 & 4.8 & 1.4 & 82.0 & 0.1 & 5.0 & 1.1 & 68.9 & 0.1 & 7.4 & 1.5 \\
\hline 5.5 & 25 & 78.1 & 0.2 & 5.4 & 1.4 & 86.4 & 0.1 & 6.2 & 1.0 & 79.5 & 0.1 & bt & bt \\
\hline \multirow{4}{*}{\multicolumn{2}{|c|}{$\begin{array}{l}\text { Concentration of } \\
\text { components in the } \\
\text { primary ATPS } \\
\text { emulsion [\% } \\
\text { w/w] }\end{array}$}} & \multirow{2}{*}{\multicolumn{4}{|c|}{ pH 6}} & & & & & & & & \\
\hline & & & & & & \multicolumn{4}{|c|}{$\mathrm{pH} 7.5$} & \multicolumn{4}{|c|}{$\mathrm{pH} 9$} \\
\hline & & \multicolumn{12}{|c|}{ Temperature of the primary ATPS formation $4^{\circ} \mathrm{C}$} \\
\hline & & \multicolumn{2}{|c|}{ Bottom phase } & \multicolumn{2}{|c|}{ Top phase } & \multicolumn{2}{|c|}{ Bottom phase } & \multicolumn{2}{|c|}{ Top phase } & \multicolumn{2}{|c|}{ Bottom phase } & \multicolumn{2}{|c|}{ Top phase } \\
\hline $\begin{array}{l}\text { EO50 } \\
\text { PO50 }\end{array}$ & $\left(\mathrm{PO}_{4}\right)^{3-}$ & $\begin{array}{l}\text { EO50 } \\
\text { PO50 }\end{array}$ & $\left(\mathrm{PO}_{4}\right)^{3-}$ & $\begin{array}{l}\text { EO50 } \\
\text { PO50 } \\
\end{array}$ & $\left(\mathrm{PO}_{4}\right)^{3-}$ & $\begin{array}{l}\text { EO50 } \\
\text { PO50 }\end{array}$ & $\left(\mathrm{PO}_{4}\right)^{3-}$ & $\begin{array}{l}\text { EO50 } \\
\text { PO50 } \\
\end{array}$ & $\left(\mathrm{PO}_{4}\right)^{3-}$ & $\begin{array}{l}\text { EO50 } \\
\text { PO50 }\end{array}$ & $\left(\mathrm{PO}_{4}\right)^{3-}$ & $\begin{array}{l}\text { EO50 } \\
\text { PO50 } \\
\end{array}$ & $\left(\mathrm{PO}_{4}\right)^{3-}$ \\
\hline 3 & 12 & 32.4 & 0.5 & 2.1 & 1.9 & 39.6 & 0.3 & 4.0 & 1.6 & 41.1 & 0.2 & 4.2 & 1.7 \\
\hline 3.5 & 5 & 45.5 & 0.4 & 4.2 & 1.7 & 57.7 & 0.2 & 4.1 & 1.4 & 65.2 & 0.2 & 4.5 & 1.5 \\
\hline 4 & 18 & 57.4 & 0.4 & 4.4 & 1.6 & 64.0 & 0.2 & 4.6 & 1.4 & 65.6 & 0.2 & 4.8 & 1.4 \\
\hline 4.5 & 21 & 60.4 & 0.4 & 4.4 & 1.3 & 67.8 & 0.1 & 4.9 & 1.2 & 66.6 & 0.1 & 5.1 & 1.3 \\
\hline 5.5 & 25 & 71.1 & 0.2 & 5.1 & 1.3 & 84.6 & 0.1 & 6.2 & 1.2 & 72.3 & 0.1 & 6.6 & 1.2 \\
\hline
\end{tabular}


Table 8. The concentration of EO50PO50 and $\left(\mathrm{PO}_{4}\right)^{3-}$ in the phases of the secondary aqueous two-phase system EO50PO50/potassium phosphate (sodium chloride concentration in the primary ATPS $-0.467 \mathrm{M}$ )

\begin{tabular}{|c|c|c|c|c|c|c|c|c|c|c|c|c|c|}
\hline \multirow{4}{*}{\multicolumn{2}{|c|}{$\begin{array}{l}\text { Concentration of } \\
\text { components in the } \\
\text { primary ATPS } \\
\text { emulsion }[\% \mathrm{w} / \mathrm{w}]\end{array}$}} & \multicolumn{12}{|c|}{$\begin{array}{l}\text { The EO50PO50 and }\left(\mathrm{PO}_{4}\right)^{3-} \text { concentration after thermoseparation of top phase of the primary ATPS } \\
\text { EO50PO50/potassium phosphate [\% } / \mathrm{w}]\end{array}$} \\
\hline & & \multicolumn{4}{|c|}{ pH 6} & \multicolumn{4}{|c|}{$\mathrm{pH} 7.5$} & \multicolumn{4}{|c|}{ pH 9} \\
\hline & & \multicolumn{12}{|c|}{ Temperature of the primary ATPS formation $20^{\circ} \mathrm{C}$} \\
\hline & & \multicolumn{2}{|c|}{ Bottom phase } & \multicolumn{2}{|c|}{ Top phase } & \multicolumn{2}{|c|}{ Bottom phase } & \multicolumn{2}{|c|}{ Top phase } & \multicolumn{2}{|c|}{ Bottom phase } & \multicolumn{2}{|c|}{ Top phase } \\
\hline $\begin{array}{l}\text { EO50 } \\
\text { PO50 }\end{array}$ & $\left(\mathrm{PO}_{4}\right)^{3-}$ & $\begin{array}{l}\text { EO50 } \\
\text { PO50 }\end{array}$ & $\left(\mathrm{PO}_{4}\right)^{3-}$ & $\begin{array}{l}\text { EO50 } \\
\text { PO50 }\end{array}$ & $\left(\mathrm{PO}_{4}\right)^{3-}$ & $\begin{array}{l}\text { EO50 } \\
\text { PO50 }\end{array}$ & $\left(\mathrm{PO}_{4}\right)^{3-}$ & $\begin{array}{l}\text { EO50 } \\
\text { PO50 }\end{array}$ & $\left(\mathrm{PO}_{4}\right)^{3-}$ & $\begin{array}{l}\text { EO50 } \\
\text { PO50 }\end{array}$ & $\left(\mathrm{PO}_{4}\right)^{3-}$ & $\begin{array}{l}\text { EO50 } \\
\text { PO50 }\end{array}$ & $\left(\mathrm{PO}_{4}\right)^{3-}$ \\
\hline 3 & 12 & 37.1 & 0.4 & 3.8 & 0.9 & 48.8 & 0.1 & 4.0 & 0.5 & 54.4 & 0.4 & 3.1 & 0.5 \\
\hline 3.5 & 5 & 48.8 & 0.4 & 4.4 & 0.7 & 52.8 & 0.1 & 4.5 & 0.4 & 55.3 & 0.2 & 4.5 & 0.4 \\
\hline 4 & 18 & 59.7 & 0.2 & 4.7 & 0.6 & 64.1 & 0.1 & 5.2 & 0.4 & 60.9 & 0.1 & 4.9 & 0.4 \\
\hline 4.5 & 21 & 61.8 & 0.2 & 5.7 & 0.6 & 66.7 & 0.1 & 5.6 & 0.3 & 64.0 & 0.1 & 4.3 & 0.4 \\
\hline 5.5 & 25 & 62.4 & 0.1 & 5.7 & 0.3 & 69.0 & 0.1 & 9.6 & 0.3 & 70.6 & 0.1 & 6.3 & 0.3 \\
\hline \multirow{4}{*}{\multicolumn{2}{|c|}{$\begin{array}{l}\text { Concentration of } \\
\text { components in the } \\
\text { primary ATPS } \\
\text { emulsion [\% } \\
\text { w/w] }\end{array}$}} & \multirow{2}{*}{\multicolumn{4}{|c|}{$\mathrm{pH} 6$}} & & & & & & & & \\
\hline & & & & & & & & & & \multicolumn{4}{|c|}{$\mathrm{pH} 9$} \\
\hline & & \multicolumn{12}{|c|}{ Temperature of the primary ATPS formation $4^{\circ} \mathrm{C}$} \\
\hline & & \multicolumn{2}{|c|}{ Bottom phase } & \multicolumn{2}{|c|}{ Top phase } & \multicolumn{2}{|c|}{ Bottom phase } & \multicolumn{2}{|c|}{ Top phase } & \multicolumn{2}{|c|}{ Bottom phase } & \multicolumn{2}{|c|}{ Top phase } \\
\hline $\begin{array}{l}\text { EO50 } \\
\text { PO50 }\end{array}$ & $\left(\mathrm{PO}_{4}\right)^{3-}$ & $\begin{array}{l}\text { EO50 } \\
\text { PO50 }\end{array}$ & $\left(\mathrm{PO}_{4}\right)^{3-}$ & $\begin{array}{l}\text { EO50 } \\
\text { PO50 }\end{array}$ & $\left(\mathrm{PO}_{4}\right)^{3-}$ & $\begin{array}{l}\text { EO50 } \\
\text { PO50 }\end{array}$ & $\left(\mathrm{PO}_{4}\right)^{3-}$ & $\begin{array}{l}\text { EO50 } \\
\text { PO50 } \\
\end{array}$ & $\left(\mathrm{PO}_{4}\right)^{3-}$ & $\begin{array}{l}\text { EO50 } \\
\text { PO50 } \\
\end{array}$ & $\left(\mathrm{PO}_{4}\right)^{3-}$ & $\begin{array}{l}\text { EO50 } \\
\text { PO50 } \\
\end{array}$ & $\left(\mathrm{PO}_{4}\right)^{3-}$ \\
\hline 3 & 12 & 44.2 & 0.7 & 4.0 & 0.9 & 48.9 & 0.3 & 3.4 & 0.6 & 40.0 & 0.4 & 3.9 & 0.4 \\
\hline 3.5 & 5 & 50.1 & 0.5 & 5.0 & 0.8 & 49.3 & 0.2 & 4.5 & 0.4 & 49.1 & 0.4 & 4.9 & 0.4 \\
\hline 4 & 18 & 51.2 & 0.5 & 5.1 & 0.5 & 53.7 & 0.1 & 4.9 & 0.4 & 52.9 & 0.2 & 5.3 & 0.2 \\
\hline 4.5 & 21 & 57.7 & 0.2 & 5.8 & 0.3 & 58.0 & 0.1 & 5.5 & 0.3 & 59.1 & 0.1 & 5.7 & 0.2 \\
\hline 5.5 & 25 & 60.5 & 0.2 & 6.4 & 0.6 & 64.1 & 0.1 & 6.8 & 0.2 & 72.2 & 0.1 & 6.2 & 0.2 \\
\hline
\end{tabular}

Table 9. The concentration of EO50PO50 and $\left(\mathrm{PO}_{4}\right)^{3-}$ in the phases of the secondary aqueous two-phase system EO50PO50/potassium phosphate (sodium chloride concentration in the primary ATPS $-0.85 \mathrm{M}$ )

\begin{tabular}{|c|c|c|c|c|c|c|c|c|c|c|c|c|c|}
\hline \multirow{4}{*}{\multicolumn{2}{|c|}{$\begin{array}{l}\text { Concentration of } \\
\text { components in the } \\
\text { primary ATPS } \\
\text { emulsion }[\% \mathrm{w} / \mathrm{w}]\end{array}$}} & \multicolumn{12}{|c|}{$\begin{array}{l}\text { The EO50PO50 and }\left(\mathrm{PO}_{4}\right)^{3-} \text { concentration after thermoseparation of top phase of the primary ATPS } \\
\text { EO50PO50/potassium phosphate [\% } / \mathrm{w}]\end{array}$} \\
\hline & & \multicolumn{4}{|c|}{$\mathrm{pH} 6$} & \multicolumn{4}{|c|}{$\mathrm{pH} 7.5$} & \multicolumn{4}{|c|}{$\mathrm{pH} 9$} \\
\hline & & \multicolumn{12}{|c|}{ Temperature of the primary ATPS formation $20^{\circ} \mathrm{C}$} \\
\hline & & \multicolumn{2}{|c|}{ Bottom phase } & \multicolumn{2}{|c|}{ Top phase } & \multicolumn{2}{|c|}{ Bottom phase } & \multicolumn{2}{|c|}{ Top phase } & \multicolumn{2}{|c|}{ Bottom phase } & \multicolumn{2}{|c|}{ Top phase } \\
\hline $\begin{array}{l}\text { EO50 } \\
\text { PO50 }\end{array}$ & $\left(\mathrm{PO}_{4}\right)^{3-}$ & $\begin{array}{l}\text { EO50 } \\
\text { PO50 }\end{array}$ & $\left(\mathrm{PO}_{4}\right)^{3-}$ & $\begin{array}{l}\text { EO50 } \\
\text { PO50 }\end{array}$ & $\left(\mathrm{PO}_{4}\right)^{3-}$ & $\begin{array}{l}\text { EO50 } \\
\text { PO50 }\end{array}$ & $\left(\mathrm{PO}_{4}\right)^{3-}$ & $\begin{array}{l}\text { EO50 } \\
\text { PO50 }\end{array}$ & $\left(\mathrm{PO}_{4}\right)^{3-}$ & $\begin{array}{l}\text { EO50 } \\
\text { PO50 }\end{array}$ & $\left(\mathrm{PO}_{4}\right)^{3-}$ & $\begin{array}{l}\text { EO50 } \\
\text { PO50 }\end{array}$ & $\left(\mathrm{PO}_{4}\right)^{3-}$ \\
\hline 3 & 12 & 30.0 & 0.2 & 5.2 & 0.2 & 31.1 & 0.3 & 4.8 & 0.1 & 32.7 & 0.1 & 5.4 & 0.2 \\
\hline 3.5 & 5 & 35.3 & 0.2 & 6.0 & 0.1 & 38.3 & 0.1 & 6.2 & 0.1 & 39.4 & 0.1 & 6.6 & 0.2 \\
\hline 4 & 18 & 42.4 & 0.1 & 6.7 & 0.1 & 43.3 & 0.1 & 6.2 & 0.0 & 47.8 & 0.1 & 10.2 & 0.2 \\
\hline 4.5 & 21 & 52.1 & 0.1 & 6.8 & 0.1 & 55.2 & 0.1 & 8.5 & 0.0 & 56.4 & 0.1 & 11.7 & 0.0 \\
\hline 5.5 & 25 & \multicolumn{12}{|c|}{$\mathrm{bt}$} \\
\hline \multirow{4}{*}{\multicolumn{2}{|c|}{$\begin{array}{l}\text { Concentration of } \\
\text { components in the } \\
\text { primary ATPS } \\
\text { emulsion [\% } \\
\text { w/w] }\end{array}$}} & \multirow{2}{*}{\multicolumn{4}{|c|}{$\mathrm{pH} 6$}} & & & & & & & & \\
\hline & & & & & & & $\mathrm{pH}$ & & & \multicolumn{4}{|c|}{ pH 9} \\
\hline & & \multicolumn{12}{|c|}{ Temperature of the primary ATPS formation $4^{\circ} \mathrm{C}$} \\
\hline & & \multicolumn{2}{|c|}{ Bottom phase } & \multicolumn{2}{|c|}{ Top phase } & \multicolumn{2}{|c|}{ Bottom phase } & \multicolumn{2}{|c|}{ Top phase } & \multicolumn{2}{|c|}{ Bottom phase } & \multicolumn{2}{|c|}{ Top phase } \\
\hline $\begin{array}{l}\text { EO50 } \\
\text { PO50 } \\
\end{array}$ & $\left(\mathrm{PO}_{4}\right)^{3-}$ & $\begin{array}{l}\text { EO50 } \\
\text { PO50 } \\
\end{array}$ & $\left(\mathrm{PO}_{4}\right)^{3-}$ & $\begin{array}{l}\text { EO50 } \\
\text { PO50 }\end{array}$ & $\left(\mathrm{PO}_{4}\right)^{3-}$ & $\begin{array}{l}\text { EO50 } \\
\text { PO50 } \\
\end{array}$ & $\left(\mathrm{PO}_{4}\right)^{3-}$ & $\begin{array}{l}\text { EO50 } \\
\text { PO50 } \\
\end{array}$ & $\left(\mathrm{PO}_{4}\right)^{3-}$ & $\begin{array}{l}\text { EO50 } \\
\text { PO50 } \\
\end{array}$ & $\left(\mathrm{PO}_{4}\right)^{3-}$ & $\begin{array}{l}\text { EO50 } \\
\text { PO50 } \\
\end{array}$ & $\left(\mathrm{PO}_{4}\right)^{3-}$ \\
\hline 3 & 12 & 29.2 & 0.3 & 5.3 & 0.1 & - & 33.3 & 0.2 & 6.0 & 0.2 & & & \\
\hline 3.5 & 5 & 40.8 & 0.2 & 5.4 & 0.1 & 29.5 & 0.2 & 4.9 & 0.1 & 39.7 & 0.1 & 6.2 & 0.2 \\
\hline 4 & 18 & 47.4 & 0.2 & 5.6 & 0.1 & 34.9 & 0.2 & 5.6 & 0.1 & 46.4 & 0.1 & 7.6 & 0.1 \\
\hline 4.5 & 21 & 53.4 & 0.2 & 5.6 & 0.1 & 46.8 & 0.2 & 6.5 & 0.0 & 55.2 & 0.1 & 9.6 & 0.1 \\
\hline 5.5 & 25 & & & & & & & & & & & & \\
\hline
\end{tabular}

- formation of the primary aqueous two-phase system did not occur

bt - formation of the secondary aqueous two-phase system did not occur 
Table 10. $\mathrm{Cl}^{-}$partition coefficients in the secondary aqueous two-phase systems EO50PO50/potassium phosphate

\begin{tabular}{|c|c|c|c|c|c|}
\hline \multicolumn{2}{|c|}{$\begin{array}{c}\text { Concentration of } \\
\text { components in the primary } \\
\text { ATPS emulsion }[\% \mathrm{w} / \mathrm{w}]\end{array}$} & \multirow{2}{*}{$\begin{array}{c}\text { Concentration } \\
\text { of } \mathrm{NaCl} \text { in } \\
\text { the primary } \\
\text { ATPS } \\
\text { emulsion } \\
{[\mathrm{M}]}\end{array}$} & \multirow[t]{2}{*}{$p H$} & \multicolumn{2}{|c|}{$\mathrm{Cl}^{-}$partition coefficient } \\
\hline EO50PO50 & $\mathrm{PO}_{4}{ }^{3-}$ & & & $4^{\circ} \mathrm{C}$ & $20^{\circ} \mathrm{C}$ \\
\hline 12 & 3 & \multirow{15}{*}{0.467} & \multirow{5}{*}{6} & 2.29 & 3.06 \\
\hline 15 & 3.5 & & & 2.36 & 3.26 \\
\hline 18 & 4 & & & 2.55 & 3.68 \\
\hline 21 & 4.5 & & & 3.10 & 3.86 \\
\hline 25 & 5.5 & & & 3.66 & 4.19 \\
\hline 12 & 3 & & \multirow{5}{*}{7.5} & 3.05 & 2.96 \\
\hline 15 & 3.5 & & & 3.03 & 3.21 \\
\hline 18 & 4 & & & 3.27 & 3.30 \\
\hline 21 & 4.5 & & & 3.66 & 3.38 \\
\hline 25 & 5.5 & & & 3.67 & 4.34 \\
\hline 12 & 3 & & \multirow{5}{*}{9} & 3.30 & 3.18 \\
\hline 15 & 3.5 & & & 2.29 & 3.38 \\
\hline 18 & 4 & & & 2.48 & 3.43 \\
\hline 21 & 4.5 & & & 3.11 & 3.55 \\
\hline 25 & 5.5 & & & 4.26 & 4.19 \\
\hline 12 & 3 & \multirow{15}{*}{0.850} & \multirow{5}{*}{6} & 4.75 & 4.74 \\
\hline 15 & 3.5 & & & 5.12 & 6.20 \\
\hline 18 & 4 & & & 5.75 & 6.70 \\
\hline 21 & 4.5 & & & 6.36 & 7.18 \\
\hline 25 & 5.5 & & & 6.51 & 7.35 \\
\hline 12 & 3 & & \multirow{5}{*}{7.5} & - & 5.94 \\
\hline 15 & 3.5 & & & 5.32 & 6.53 \\
\hline 18 & 4 & & & 6.65 & 7.21 \\
\hline 21 & 4.5 & & & 6.92 & 7.82 \\
\hline 25 & 5.5 & & & 7.32 & 8.52 \\
\hline 12 & 3 & & \multirow{5}{*}{9} & 4.22 & 5.17 \\
\hline 15 & 3.5 & & & 4.70 & 5.60 \\
\hline 18 & 4 & & & 5.53 & 6.07 \\
\hline 21 & 4.5 & & & 5.94 & 6.71 \\
\hline 25 & 5.5 & & & 6.48 & 6.96 \\
\hline
\end{tabular}

- formation of an aqueous two-phase system did not occur

\subsection{Chloride anion partition coefficients in primary and secondary systems}

The chloride anion partition coefficients were calculated for primary and secondary EO50PO50/potassium phosphate systems, which were supplemented with $0.467 \mathrm{M}$ and $0.85 \mathrm{M}$ sodium chloride (Table 5). No chloride anion partition coefficients were determined in the systems containing $0.085 \mathrm{M}$ of sodium chloride. It was caused by low concentration of the anion in the analysed samples lower than the detection threshold of the used concentration measurement method. The values of chloride anion partition coefficients in primary systems were lower than 1 and contained between 0.15 0.47. It means that chloride anion in the primary system had higher affinity to the bottom phosphate- 
rich phase. The salts introduced to the two-phase systems are subject to division between phases depending on their hydrophobicity and affinity to a given phase. According to the Hofmeister series, the hydrophobicity of anions decreases in the following way: $\mathrm{SCN}^{-}>\mathrm{ClO}_{4}>\mathrm{Cl}^{-}>\mathrm{CH}_{2} \mathrm{COO}^{-}>\mathrm{HPO}_{4}{ }^{2-}$ $>\mathrm{PO}_{4}{ }^{3-}$. In a two-phase EO50PO50/phosphate system, the chloride ion as a more hydrophobic ion should migrate to the hydrophobic phase (polymer) (Berggren et al., 1995). An opposite phenomenon was observed in this study. The behavior of chloride ions can be explained by their role in the stabilisation of water molecule structures out of the polymer interaction zone, which enables dehydratation of polymer molecules (Materna et al., 2004). This hypothesis is confirmed by earlier observations regarding the increase of polymer concentration in the top phase along with the increase in the sodium chloride concentration in the primary system.

The partition coefficients of the separated molecules are often presented as functions of tie line length (de Oliveira et al., 2007). It was concluded that when the length of the tie line crossing the operational point (examined system) increased, the partition coefficient of the chloride ion decreased. It meant that with the increase of EO50PO50 and potassium phosphate concentrations in the system, the concentration of chloride anion in the bottom phase increased as well. Lower values of the chloride anion partition coefficient were also observed in the two-phase systems that contained $0.85 \mathrm{M}$ of sodium chloride.

Chloride ions affect the migration direction and efficiency of the separated proteins e.g. during lysozyme extraction in PEG/sulphate system. Introducing chloride ion into the system, directed the migration of that enzyme to the top phase (Su and Chiang, 2006).

In the secondary systems (after thermoseparation), the chloride anion partition coefficients were greater than 1 and amounted to 2.29-8.52 (Table 10). It was observed that with the increase of sodium chloride concentration and the increase of the EO50PO50 polymer and phosphate concentrations in the primary systems, there was an increase in the chloride anion partition coefficient values in the secondary systems. Chloride anions migrated to the water phase (top phase) of the secondary system in a preferential way. During thermoseparation, chloride anions gathered in the aqueous phase as more hydrophilic than the polymer molecules, while the polymer, due to dehydration, was separated easily and more rapidly (Materna et al., 2004). Additionally, Johansson et al. (1997) proved that polymer dehydration was enhanced with the increase of salt hydrophilicity. During thermoseparation, the presence of more hydrophobic $\mathrm{NaClO}_{4}$ (instead of more hydroplilic $\mathrm{NaCl}$ ) increased the water content in the polymer rich phase.

\section{CONCLUSIONS}

Based on the phase diagrams in the primary systems, it was concluded that the most suitable, highest two-phase region is characteristic for systems which were formed with EO50PO50 and potassium phosphates of $\mathrm{pH} \mathrm{9,} \mathrm{containing} \mathrm{maximum} \mathrm{concentration} \mathrm{of} \mathrm{sodium} \mathrm{chloride} \mathrm{used} \mathrm{in} \mathrm{the} \mathrm{study,} \mathrm{which}$ amounted to $0.85 \mathrm{M}$. As a result, these systems can be most useful for separating proteins because their formation requires the lowest number of chemicals. Moreover, during protein extraction, they will be most resistant to dilutions as a result of introducing substantial volumes of solution containing the isolated protein to such a system. In the secondary systems created as a result of polymer phase (top phase) thermoseparation in primary systems, the maximum concentration of the recovered polymer in the bottom phase amounted to over $85 \%$. In turn, the lowest observed EO50PO50 concentration in the top phase was slightly higher than $2 \%$. The partition coefficient values for the chloride anion in the primary systems are lower than 1 and greater than 1 in the secondary system. It means that the chloride anion preferentially migrates to the phases characterised by higher hydrophilicity. 


\section{SYMBOLS}

$a, b, c, d \quad$ equation coefficients

ATPS aqueous two-phase system

$C \quad \mathrm{Cl}^{-}$anion concentration, $\% \mathrm{w} / \mathrm{v}$

$C P \quad$ cloud point, ${ }^{\circ} \mathrm{C}$

EO50PO50 random copolymer of composed of oxyethylene groups (50\%) and oxypropylene groups $(50 \%)$

$K \quad \mathrm{Cl}^{-}$anion partition coefficient

PEG polyethylene glycol

$T L \quad$ tie line

TLL tie line length, \%

$X \quad \mathrm{PO}_{4}{ }^{3-}$ anion concentration, $\% \mathrm{w} / \mathrm{w}$

$\triangle X \quad$ difference of $\mathrm{PO}_{4}{ }^{3}$ anion concentration between the top and bottom phases

$Y \quad$ EO50PO50 concentration, \% $\mathrm{w} / \mathrm{w}$

$\Delta Y \quad$ difference of EO50PO50 concentration between the top and bottom phases

Subscripts

1,2 indices, top and bottom phases, respectively

\section{REFERENCES}

Adler N., 1965. Residual ethylene oxide and ethylene glycol in ethylene oxide sterilized pharmaceuticals. $J$. Pharm. Sci., 54, 735-742. DOI: 10.1002/jps.2600540516.

Albertsson P. A., 1986. Partition of Cell Particles and Macromolecules. Wiley, New York.

Albertsson P. A., Tjerneld F., 1994. Phase diagrams, In: Walter H., Johansson G. (Eds.), Methods in enzymology, vol. 228. Academic Press, San Diego, 3-13.

Alderton G., Fevold H.L., 1946. Direct crystallization of lysozyme from egg white and some crystalline salts of lysozyme. J. Biol. Chem., 164, 1-5.

Bakshi M. S., Sachar S., Yoshimura T., Esumi K., 2004. Association behavior of poly(ethylene oxide)poly(propylene oxide)-poly(ethylene oxide) block copolymers with cationic surfactants in aqueous solution. J. Colloid Interface Sci., 278, 224-233. DOI: 10.1016/j.jcis.2004.05.025.

Banik R. M., Santhiagu A., Kanari B., Sabarinath C. and Upadhyay S. N., 2003. Technological aspects of extractive fermentation using aqueous two-phase systems. World J. Microbiol. Biotechnol., 19, 337-348. DOI: 10.1023/A:1023940809095.

Berggren K., Johansson H. O., Tjerneld F., 1995. Effects of salts and the surface hydrophobicity of proteins on partitioning in aqueous two-phase systems containing thermoseparating ethylene oxide-propylene oxide copolymers. J. Chromatogr. A, 718, 67-79. DOI: 10.1016/0021-9673(95)00657-5.

Cunha M. T., Cabral J. M. S., Tjerneld F., Aires-Barros M. R., 2000. Effect of salts and surfactants on the partitioning of Fusarium solani pisi cutinase in aqueous two-phase systems of thermoseparating ethylene oxide/propylene oxide random copolymer and hydroxypropyl starch. Bioseparation, 9, 203-209. DOI: 10.1023/A:1008132108117.

Cunha M. T., Tjerneld F., Cabral J. M. S, Aires-Barros M. R., 1998. Effect of electrolytes and surfactants on the thermoseparation of an ethylene oxide-propylene oxide random copolymer in aqueous solution. J. Chromatogr. B: Biomed. Sci. Appl., 711, 53-60. DOI: 10.1016/S0378-4347(98)00021-8.

Czaczyk K., Cyplik P., Mueller A., 2003. The method of determination of inorganic anions in water by use of HPLC with UV detection. Aparatura Badawcza i Dydaktyczna, 8, 27-32 (in Polish).

Dembczyński R., Białas W., Jankowski T., 2010b. Recycling of phase components during lysozyme extraction from hen egg white in the EO50PO50/K2HPO4 aqueous two-phase system. Biochem. Eng. J., 51, 24-31. DOI: 10.1016/j.bej.2010.04.011.

Dembczyński R., Białas W., Regulski K., Jankowski T., 2010a. Lysozyme extraction from hen egg white in an aqueous two-phase system composed of ethylene oxide-propylene oxide thermoseparating copolymer and potassium phosphate. Process Biochem., 45, 369-374. DOI:10.1016/j.procbio.2009.10.011. 
de Oliveira M. C., de Abreu Filho M. A. N., Pessôa Filho P. A., 2007. Phase equilibrium and protein partitioning in aqueous two-phase systems containing ammonium carbamate and block copolymers PEO-PPO-PEO. Biochem. Eng. J., 37, 311-318. DOI: 10.1016/j.bej.2007.05.010.

Dyr J. E. and Suttnar J., 1997. Separation used for purification of recombinant proteins. J. Chromatogr. B: Biomed. Sci. Appl., 699, 383-401. DOI: 10.1016/S0378-4347(97)00201-6.

Elversson J., Millqvist-Fureby A., 2005. Aqueous two-phase systems as a formulation concept for spray-dried protein. Int. J. Pharm., 294, 73-87. DOI: 10.1016/j.jpharm.2005.01.015.

Johansson H.-O., Karlstrom G., Tjerneld F., 1997. Temperature-induced phase partitioning of peptides in water solutions of ethylene oxide and propylene oxide random copolymers. Biochim. Biophys. Acta, 1335, 315-325. DOI: 10.1016/S0304-4165(96)00150-X.

Kopeć W., Chrzanowska J., Karkoszka K., Lorenc J., Polanowski A., Szałak T., Trziszka T., 2000. A method of obtaining a preparation of lysozyme salt. Bulletin of the Polish Patent Office, 15 (693), 29-30 (in Polish).

Kepka C., Collet E.,Roos F., Tjerneld F., Veide A., 2005. Two-step recovery for tryptophan tagged cutinase: Interfacing aqueous two-phase extraction and hydrophobic interaction chromatography. J. Chromatogr. A, 1075, 33-41. DOI: 10.1016/j.chroma.2005.03.054.

Leja K., Dembczyński R., Białas W., Jankowski T., 2009. Production of dry Lactobacillus rhamnosus GG preparations by spray drying and lyophilization in aqueous two-phase systems. Acta Sci. Pol., Technol. Aliment., 8, 39-49.

Li W., Lin D.-Q., Zhu Z.-Q., 2000. Measurement of water activities and prediction of liquid-liquid equilibria for water + ethylene oxide-propylene oxide random copolymer + ammonium sulfate systems. Fluid Phase Equilib., 175, 7-18. DOI: 10.1016/S0378-3812(00)00452-0.

Li W., Zhu Z.-Q., Lin D.-Q., 1999. Liquid-liquid equilibria of aqueous two-phase systems containing ethylene oxide-propylene oxide random copolymer and ammonium sulfate. J. Chem. Eng. Data, 44, 921-925. DOI: 10.1021/je990049o.

Lienqueo M.E. and Asenjo J.A., 2000. Use of expert systems for the synthesis of downstream protein processes. Comput. Chem. Engng., 24, 2339-2350. DOI: 10.1016/S0098-1354(00)00590-1.

Materna K., Cote G., Szymanowski J., 2004. Cloud point of aqueous solutions containing oxyethylated methyl dodecanoates: effects of surfactant hydrophilicity, nature of added electrolyte and water activity. J. Colloid Interface Sci., 269, 466-471. DOI: 10.1016/j.jcis.2003.08.002.

Merchuk J.C., Andrews B. A., Asenjo J.A., 1998. Aqueous two-phase systems for protein separation. Studies on phase inversion. J. Chromatogr. B: Biomed. Sci. Appl., 711, 285-293. DOI: 10.1016/S0378-4347(97)00594-X.

Mishima K., Matsuyama K., Ezawa M., Taruta Y., Takarabe S., Nagatani M., 1998. Interfacial tension of aqueous two-phase systems containing poly(ethylene glycol) and dipotassium hydrogenphosphate. J. Chromatogr. B: Biomed. Sci. Appl., 711, 313-318. DOI: 10.1016/S0378-4347(97)00660-9.

Mistry S.L., Kaul A., Merchuk J.C., Asenjo J.A., 1996. Mathematical modelling and computer simulation of aqueous two-phase continuous protein extraction. J. Chromatogr. A, 741, 79-84. DOI: 10.1016/00219673(96)00179-3.

Owen R.O., Chase H.A., 1997. Direct purification of lysozyme using continuous counter-current expanded bed adsorption. J. Chromatogr. A, 757, 41-49. DOI: 10.1016/S0021-9673(96)00680-2.

Pereira M., Wu Y.-T., Venancio A., Teixeira J., 2003. Aqueous two-phase extraction using thermoseparating polymer: a new system for the separation of endo-polygalacturonase. Biochem. Eng. J., 15, 131-138. DOI: 10.1016/S1369-703X(02)00190-0.

Przybycien T. M., Pujar N. S. and Steele L. M., 2004. Alternative bioseparation operations: life beyond packedbed chromatography. Curr. Opin. Biotech., 15, 469-478. DOI: 10.1016/j.copbio.2004.08.008.

Rito-Palomares M., 2004. Practical application of aqueous two-phase partition to process development for the recovery of biological products. J. Chromatogr. B: Biomed. Sci. Appl., 807, 3-11. DOI: 10.1016/j.jchromb.2004.01.008.

Rosa P. A. J., Azvedo A. M., Ferreira I. F., Sommerfeld S., Bäcker W., Aires-Barros M. R., 2009. Downstream processing of antibodies: Single-stage versus multi-stage aqueous two-phase extraction. J. Chromatogr. A, 1216, 8741-8749. DOI: 10.1016/j.chroma.2009.02.024.

Salabat A., 2001. The influence of salts on the phase composition in aqueous two-phase systems: experiments and predictions. Fluid Phase Equilib., 187-188, 489-498. DOI: 10.1016/S0378-3812(01)00569-6.

Sarubbo L.A., Oliveira L.A., Porto A.L.F., Duarte H.S., Carneiro-Leão A.M.A., Lima-Filho J.L., Campos-Takaki G.M., Tambourgi E.B., 2000. New aqueous two-phase system based on cashew-nut tree gum and poly(ethylene glycol). J. Chromatogr. B: Biomed. Sci. Appl., 743, 79-84. DOI: 10.1016/S0378-4347(99)00516-2. 
Schügerl K., Hubbuch J., 2005. Integrated bioprocesses. Curr. Opin. Biotech., 8, 294-300. DOI: 10.1016/j.mib.2005.01.002.

Sebastiao M. J., Cabral J.M. and Aires-Barros M. R., 1996. Improved purification protocol of a Fusarium solani pisi recombinant cutinase by phase partitioning in aqueous two-phase systems of polyethylene glycol and phosphate. Enzyme Microb. Tech., 18, 251-260. DOI: 10.1016/0141-0229(95)00045-3.

Silverio S.C., Rodriguez O., Teixeira J.A., Macedo E.A., 2010. Liquid-liquid equlibria of UCON + (sodium or potassium) phosphate salt aqueous two-phase systems at $23^{\circ} \mathrm{C}$. J. Chem. Eng. Data, 55, 1285-1288. DOI: $10.1021 /$ je900628m.

Sinha J., Dey P. K., Panda T., 2000. Aqueous two-phase: the system of choice for extractive fermentation. Appl. Microbiol. Biot., 54, 476-486. DOI: 10.1007/s002530000342.

Su C.-K., Chiang B.H., 2006. Partitioning and purification of lysosyme from chicken egg white using aqueous two-phase system. Process Biochem., 41, 257-263. DOI: 10.1016/j.procbio.2005.06.026.

Svensson M., Berggren K., Veide A., Tjerneld F., 1999. Aqueous two-phase systems containing self-associating block copolymers. Partitioning of hydrophilic and hydrophobic biomolecules. J. Chromatogr. A, 839, 71-83. DOI: 10.1016/S0021-9673(99)00038-2.

Torchilin V.P., 2001. Structure and design of polymeric surfactant-based drug delivery systems. J. Control. Release, 73, 137-172. DOI: 10.1016/0141-0229(95)00045-3.

Walter H., Brooks D.B. and Fisher D., 1985. Partitioning in Aqueous Two-Phase Systems: Theory, Methods, Uses, and Applications to Biotechnology. Academic Press, Orlando, FL.

Wu Y.-T., Zhu Z.-Q., 1999. Modeling of interfacial tension of aqueous two-phase systems. Chem. Eng. Sci., 54, 433-440. DOI: 10.1016/S0009-2509(98)00255-3.

Xu Y., de Souza M. A., Ribeiro-Pontes M., Z., Vitolo M., Pessoa-Jr A., 2001. Liquid-liquid extraction of pharmaceuticals by aqueous two-phase systems. Braz. J. Pharm. Sci., 37, 305-320.

Zafarani-Moattar M. T., Hamzehzadeh Sh., 2005. Liquid-liquid equilibria of aqueous two-phase systems containing polyethylene glycol and sodium succinate or sodium formate. Calphad Comput. Coupling Ph. Diagrams Thermochem., 29, 1-6. DOI: 10.1016/j.calphad.2005.01.004.

Zafarani-Moattar M. T., Sadeghi R., 2001. Liquid-liquid equilibria of aqueous two-phase systems containing polyethylene glycol and sodium dihydrogen phosphate or disodium hydrogen phosphate: Experiment and correlation. Fluid Phase Equilib., 181, 95-112. DOI: 10.1016/S0378-3812(01)00373-9.

Zafarani-Moattar M. T., Tolouei S., 2008. Liquid-liquid equilibria of aqueous two-phase systems containing polyethylene glycol 4000 and di-potassium tartate, potassium sodium tartrate, or di-potassium oxalate: Experiment and correlation. Calphad Comput. Coupling Ph. Diagrams Thermochem., 32, 655-660. DOI: 10.1016/j.calphad.2008.09.006.

Zaslavsky B. Y., 1995. Aqueous Two-Phase Partitioning - Physical Chemistry and Bioanalytical Applications. Marcel Dekker Inc., New York, 82.

Zielińska-Dawidziak M., Jankowski T., 2002a. The separation of biotechnology products in aqueous two-phase systems. Part I - Theoretical background. Biotechnologia, 1 (56), 142-152 (in Polish).

Zielińska-Dawidziak M., Jankowski T., 2002b. The separation of biotechnology products in aqueous two-phase systems. Part II - Applications. Biotechnologia, 2 (57), 102-112 (in Polish).

Received 28 November 2011

Received in revised form 23 July 2012

Accepted 30 July 2012 